\title{
The art of indigeneity: Aesthetics and competition in Mexican economies of culture
}

Article

Accepted Version

Cant, A. (2016) The art of indigeneity: Aesthetics and competition in Mexican economies of culture. Ethnos, 81 (1). pp. 152-177. ISSN 0014-1844 doi:

https://doi.org/10.1080/00141844.2014.921218 Available at https://centaur.reading.ac.uk/86147/

It is advisable to refer to the publisher's version if you intend to cite from the work. See Guidance on citing.

To link to this article DOI: http://dx.doi.org/10.1080/00141844.2014.921218

Publisher: Taylor \& Francis

All outputs in CentAUR are protected by Intellectual Property Rights law, including copyright law. Copyright and IPR is retained by the creators or other copyright holders. Terms and conditions for use of this material are defined in the End User Agreement.

$\underline{\text { www.reading.ac.uk/centaur }}$

\section{CentAUR}


Central Archive at the University of Reading

Reading's research outputs online 


\title{
The Art of Indigeneity: Aesthetics and Competition in Mexican Economies of Culture
}

2016. 'The Art of Indigeneity: Aesthetics and Competition in Mexican Economies of Culture.' Ethnos: Journal of Anthropology 81(1): 152-177.

\begin{abstract}
Based upon ethnographic research with woodcarvers in Oaxaca, Mexico, this paper investigates the role that aesthetic practices play in economic competition in cultural markets. I explain how one family has become the most successful artisans in their village by aesthetically referencing the indigenous art that is highly sought after by the North American ethnic art market. By reformulating Bourdieu's analysis of artistic fields, I argue that aesthetic competition should be theorised at the level of genres, which allows insight into how individual aesthetic innovations may transform the fields in which art is produced and circulated. I show that by referencing indigeneity, this successful family not only accesses a new market, but also renders their work more authoritative than the carvings of their neighbours, which aesthetically reference Mexican "artesanías" (craftwork). In so doing, they not only earn more money, but also change the ways that Oaxacan woodcarvings are valued in general.
\end{abstract}

\section{Key words}

Aesthetics, art, competition, value, Mexico

Word Count 9348

\section{Acknowledgements}

The research for this paper was generously funded by the Emslie Horniman Fund of the Royal Anthropological Institute. I would like to thank Andrew Sanchez, Matthew Engelke, Barbara Bodenhorn, Lynn Stephen and Martin Holbraad for their feedback on earlier versions of this work. I am also grateful to Ethnos' editorial team and anonymous reviewer for their very insightful suggestions which have greatly enhanced this piece. I also thank the Max Planck Institute for Social Anthropology (Halle, Germany) for institutional support during the initial preparation of this manuscript. 


\section{Introduction}

In the hot, dry summer of 2009, representatives from Mexico's Fondo Nacional para el Fomento de las Artesanías (National Fund for the Development of Craftwork, hereafter FONART) began a two week project called Manitas Mágicas (“Little Magic Hands”) in San Martín Tilcajete, a small village in the southern state of Oaxaca. Manitas Mágicas is a series of short films and radio reports about the children of artisans in different craft communities throughout Mexico, which were produced as part of FONART's general objective to coordinate and promote craft production across the country. ${ }^{1}$ Like the many tourists and folk art collectors who also make the short journey to San Martín from Oaxaca City throughout the year, the project coordinators were drawn to the village by the elaborate Oaxacan woodcarvings that are hand-produced in small household workshops. After an initial consideration of the village's concrete covered square as the setting of the film, the filmmakers decided that the large, sunny and aesthetically pleasing workshop of Miguel and Catalina García was a better filming location. ${ }^{2}$ While it may at first appear to have been a technical decision based on considerations of lighting and space, when considered in the larger social context of woodcarving in San Martín, it becomes clear that FONART's choice to film in the Garcías' workshop reflects larger processes that govern the markets for Oaxacan woodcarvings in particular, and cultural production in general.

Residents of San Martín hold communal titles to their land and the village's municipal authority is governed through the Oaxacan state-sanctioned arrangement of usos y costumbres: "traditional rule" via the cargo system, in which adult males accrue authority and power within the civil hierarchy through service to the community. ${ }^{3}$ As such, the decision by FONART to represent the community through a private workshop seemed generally at odds with other state 
governance initiatives in Oaxaca. However, when FONART began filming at the Garcías' workshop their neighbours were not surprised; in recent years Miguel and Catalina have become the best-known artisans in the village, attracting many clients from Mexico, the United States, and as far away as Europe and Japan. Even during the low tourism season between the end of Holy Week and the beginning of summer vacations, when organised tours and independent travellers are rare sights in San Martín, the Garcías continue to welcome visitors many times a week. Their enviable success poses a puzzle that is of interest both to anthropologists and the Garcías' neighbours alike: how are they able to be so much more successful than their competitors when their work is made from the same materials, produced in the same manner, and located in the same village as other artisans?

The appearance of the FONART film crew in the Garcías' workshop is of course not incidental to the question - many anthropologists have addressed the central role that state agencies like FONART play in fomenting interest in particular types of cultural production. Often focusing on tourism, development and nation-building activities, the field has usefully highlighted both the knowledge-producing discourses associated with states' promotion of “culture," and how local people appropriate, rework and redeploy these imaginaries for their own projects and goals (Meisch 1995:98-100, 240-267; Brown 1999; Stephen 2005:152-199).

However, as these approaches usually focus on the entanglements between states, producers and markets, competition between producers is often under-theorised and taken as a straightforward consequence of participation in economies of cultural difference. While the character of competition within cultural markets has been profitably linked to the rise of entrepreneurial subjectivities (Comaroff and Comaroff 2009; de Hart 2010), there has been less attention to how 
economies of culture themselves are fashioned through the specific work practices of the individuals involved. Unlike conventional approaches to competition - which are generally based on market models that emphasise economic capital, information and innovation as the keys to success - I follow Rudi Colloredo Mansfeld in suggesting that analyses of cultural markets must address how competition is often predicated more on "expressiveness, communication, and creative responsiveness" than purely economic factors $(2002: 114 ; 122-125 ; 2011)$. Competition in cultural economies, I suggest, is better addressed as a dynamic and on-going relationship between intimate actors, who in addition to economic relations, interact within contexts coloured by social, familial and cultural dynamics.

In order to understand the nature of competition in cultural markets, this paper argues that rather than seeing the skills and knowledge of cultural producers as "assets" that individuals can invest more or less shrewdly, we must account for how producers' work practices, skills and relationships actively constitute the conceptual and economic terrains on which competition takes place (cf. Mohsini forthcoming). Where Colloredo-Mansfeld has approached these questions by focusing on the intra-community employment practices that serve "superstar" artisans in their consolidation of success (2002), my main theoretical concern here is to account for the aesthetic practices that take place within these same terrains. In so doing, I wish to further expand current research on how politics and performance in craft markets mediate relations between producers and consumers (e.g. Terrio 1999; Stephen 2005). I do so by focusing on the "art-like" qualities of craftwork, and how such qualities determine the form and value of products and the status they subsequently confer to their producers. 
My goal in this paper is to address the relative values of similar objects within the competitive world of Oaxacan woodcarving by analysing the practices through which the art-like qualities, or aesthetics, of woodcarvings are produced. I will show how artisans' aesthetic practices are both moulded by and in turn shape the markets in which their work circulates. These two processes cannot be conceptually separated from one another. Instead, I suggest that analyses of cultural markets should focus on the interrelationships between the aesthetic, sociocultural and economic processes that characterise their forms. As I will show, the Garcías' success is not based simply on a capacity for "ethnic entrepreneurship" but also depends on their ability to generate and mobilise aesthetics in a way that positions their work as both authoritative and more valuable within the Oaxacan woodcarving market. This paper therefore contributes to broader anthropological efforts to locate and interrogate the intersections between material and work practices, and the circulation of cultural objects and ideologies (Myers 2002; Marchand 2009; Makovicky 2010; Brulotte 2013).

I begin by introducing the context of the competition between the Oaxacan woodcarvers with whom I worked in San Martín Tilcajete for twenty months in 2008 and 2009. Following this, I discuss how anthropologists might analytically approach aesthetic processes, and I suggest that the aesthetics of visual arts are best conceptualised at the level of genres which are generated through the practices and expectations of many different actors. I then explain how the genre of Oaxacan woodcarving has developed around particular understandings of Mexican craftwork and how the Garcías have subsequently transformed this genre by including the aesthetic markers of "indigenous art" in their pieces. I argue that this aesthetic shift has allowed the Garcías to 
establish themselves as aesthetic authorities in San Martín, making them not only more visible within the art world of Oaxacan woodcarving, but also more successful than their neighbours.

\section{Oaxacan woodcarving and its art world}

Although San Martín Tilcajete is now best known for the production of woodcarvings, they are not a "traditional" product in the everyday sense of the word. Oaxacan woodcarvings (or “alebrijes”) are small, brightly painted figures, often of animals or popular Mexican folk characters that tourists buy as souvenirs or collectors find in galleries and stores throughout Mexico and the United States (Figure 1). They originated across the valley in the community of San Antonio Arrazola through the work of Manuel Jiménez, who established the craft in the late 1950s. They were not produced in San Martín until as recently as the mid-1970s, when a villager was employed as a purchaser for FONART and he began to encourage woodcarving amongst his neighbours. By the 1990s, woodcarving was established as a major source of income for many households, often supplementing uncertain economic returns from agriculture and migrant remittances (Chibnik 2003:23-30). San Martín has now in some ways outpaced Arrazola as a centre of woodcarving production. This appears to be due to a combination of its convenient location on the same tour route as other towns known for pottery, textiles and lively local markets, and the abilities of individuals and artisans' groups to maintain close personal relations with the bureaucrats in the Oaxacan state's various craft, economy and tourism boards. Because San Martín has become a focus for organized tours, many "commercial” workshops selling less expensive souvenir-quality pieces have been established and these also attract wholesalers who buy craft souvenir items in bulk to distribute to Mexico's large tourism destinations, like Acapulco and Cancun. ${ }^{4}$ Although San Martín is also the home of many artisans who produce 
higher-end collectable work, some folk art collectors believe that more unique and distinctive pieces can be found in Arrazola.

\section{[FIGURE 1]}

Unlike Arrazola, where Manuel Jiménez and his family continued to enjoy prominence, in the late 1990s, no real woodcarving "superstar" had emerged in San Martín, although a number of artisans had made names for themselves as producers of unique and fine quality work (Chibnik 2003:138-140; 147-173). ${ }^{5}$ By the time of my field research, however, one family had emerged as the clear winners in the Oaxacan woodcarving market. Miguel and Catalina García were just one amongst many young couples who began producing carvings together in the 1990s, but today they run the largest and most successful workshop in San Martín. They employ approximately thirty full-time waged employees, as well as pieceworkers who perform basic tasks at home, such as sanding or painting base coats on their carvings. From their small beginnings in Miguel's mother's house, their business has expanded to include a restaurant on the nearby highway and galleries in the historical centre of Oaxaca City.

The Garcías are considered by guides, gallery owners and state officials in Oaxaca's tourism and craft industries to be very successful artisans. Although tourism in Oaxaca has experienced difficulties in recent years due to the general economic downturn and frequent media reports on Oaxaca's political disruptions and Mexico's on-going drug violence, the Garcías continue to flourish and they always have a number of pieces on back-order that have been commissioned by private clients, museums and galleries. Compared to others in the village, the Garcías' level of success is striking - while many of the artisans whose workshops line the 
main street into the village generally receive between fifteen and two hundred pesos for their carvings (approximately $\$ 1$ and $\$ 15$ ), the Garcías frequently sell pieces for one thousand pesos (\$75) and their larger, more expensive work now easily fetches over ten thousand per piece (\$1000). Their friends in the tourism and craft industries explain their success as the result of high quality work, an "entrepreneurial business ethic" and good salesmanship on the part of Miguel. While these explanations are in many senses accurate, they downplay the extent to which the Garcías' success is also greatly dependent on their ability to stake out a new aesthetic territory within the existing genre of Oaxacan woodcarving.

For artisans in San Martín, carving and painting Oaxacan woodcarvings involves a great variety of aesthetic decisions which are influenced by both culturally-informed and idiosyncratic ideas about what woodcarvings should look like. Michael Chibnik reports, for example, that one artisan connects her painting style to her previous work as an embroiderer, while other carvers consider themselves "true artists" who are motivated by creative experimentation rather than market demands (2006:501-505). Indeed, assertions of individuality are central to artisans' development of legitimacy within the Oaxacan woodcarving art world. Having "un nombre" ("a name for one's self') greatly influences artisans' success: buyers are more likely to seek out work by known carvers, and artisans must build up histories of documented evidence of their work in competitions and publications in order to secure invitations from galleries and visas to show their work in the United States. Despite claims to individuality, there is an indisputable aesthetic consistency amongst the woodcarvings that cannot be accounted for via individuals' explanations of personal styles and decision making. This aesthetic consistency can be 
understood if we consider the expectations of other actors within the art world of Oaxacan woodcarving.

The small villages that dot Oaxaca's Valles Centrales region have proven particularly fertile for anthropologists researching the production and marketing of craftwork. In their studies of textiles, ceramics, woodcarvings and replica artefacts, anthropologists have investigated issues of political economy and the politics of culture, and have provided important insights into the organisation of workshops and markets, and the roles of the state, wholesalers and consumers within these structures (e.g. Cohen 1999; Stephen 2005; Brulotte 2013). In so doing, they have also effectively mapped the contours of the art worlds that are relevant to Oaxacan woodcarving and other crafts. William W. Wood's research into the art world that surrounds the production of Zapotec rugs in Teotitlán del Valle, across the Valles Centrales from San Martín, is particularly useful in this regard. In theorising this art world, Wood deploys the "community of practice" concept in order to show that the production of these aesthetic objects must be understood within the "social, cultural and spatial geography [that emerges] as a product of the lives and practices engaged in the making of Zapotec textiles" (Wood 2008: 15). In so doing, he identifies and explains how different kinds of actors actively participate in producing both textiles as objects and as a genre of craftwork. The main actors that Wood identifies as constituting this community of practice are tourists, guides, collectors, wholesalers and gallery owners, state representatives, anthropologists and artisans themselves, located both in Oaxaca and in the Southwest United States (Wood 2008: 117-161). These same groups (and in some cases the same individuals) are also constitutive of the aesthetics of Oaxacan woodcarvings. 
At first glance, tourists to Oaxaca might appear as the most obvious actors within the art world that influence Oaxacan artisanal production, as they interact directly with artisans, often in their workshops (cf. Hernández Díaz and Zafra 2005:16). However, while tourist arts have been usefully conceived as co-produced by tourists and their makers (Bruner 1996: 159), I suggest that tourists themselves do not usually contribute straightforwardly to the development of the aesthetics of tourist and ethnic arts. Rather, they learn about local aesthetics through their experiences in tourism locales and from tour guides and travel literature. In fact, I never observed tourists in San Martín making suggestions about how artisans should carve or paint woodcarvings, and in the cases where tourists placed an order for a specific piece, they expected that it would be produced in the workshop's own style. In a few instances, tourists gave input into the colour palettes or the specific form that they would like, but these options were constrained by the existent aesthetics of the woodcarvings, and they did not request pieces that could not have been recognised as generally consistent with the genre.

Tourists, therefore, cannot be taken for granted as the central force in the development of woodcarving aesthetics, as they are usually the intended recipients of these processes. In many ways they contribute to the aesthetic stability of the Oaxacan woodcarving genre through their consumption, as their expectations are based on the aesthetic conventions that are generated around them through the discourses and actions of other actors (cf. Steiner 1999). As I will show below, other actors - including other kinds of consumers - are indeed central to the aesthetic character of Oaxacan woodcarvings, although they do not influence these aesthetics in necessarily straightforward or predictable ways. The processes through which competition takes place in cultural markets therefore need to be approached using a conceptualisation of aesthetics 
that is suitable to ethnographic research. In the next section, I propose a way that aesthetics may be used as a conceptual tool in ethnography, which would allow us to better interrogate the relationships between people, objects and value.

\section{Accounting for aesthetics}

In recent years, anthropologists have begun to reconsider aesthetics as a useful theoretical frame for the discipline. While cautiously acknowledging that the concept is bound through its genealogical connections to particular Western philosophical and art-historical preoccupations (cf. Morphy, et al. 1996), anthropologists increasingly use aesthetics to make sense of a wide variety of social forms such as religion, nationalism and migration (e.g. Meyer 2009; Rowlands

2011; Werbner and Fumanti 2013). Their interest is not without reason - aesthetics seems uniquely positioned to offer a way to theorise the "sensorily emboldened" (Pinney 2004:193) aspects of everyday life, an enterprise that is at least one outcome of a decade of anthropological interest in materiality and material-cultural worlds. As such, in redeploying aesthetics many authors seek to reconnect it to sensory experience while (partially) removing its Eurocentric connotations of beauty, judgement and the visual arts. Sharman, for example, has suggested that anthropologists may take a pragmatic, anti-Kantian approach to aesthetics that emphasises "affective response[s] to salient moments in the temporal flow," allowing us to better theorise culture as "experience" rather than reducing it to "meaning" (2007:843). Likewise, Werbner and Fumanti emphasise the active and agentive potential of aesthetics, conceptualising it as a "sensuous participation" in the production of culture, which in turn may produce affectively powerful aesthetic forms (2013:149-151). 
While these new approaches have usefully drawn attention to the affective and sensuous aspects of social life, this theorising has not yet been fully considered by many who deal directly in the production and circulation of visual arts. However, as newer approaches to aesthetics privilege the senses within everyday experience, they could be especially useful for connecting people's practices to material objects in ways that avoid reducing these relationships to symbolic, economistic or political explanations (cf. Morphy and Perkins 2006: 16-20; Svašek 2007:9-11). For this reason, I suggest that aesthetics is particularly helpful for investigating visual artistic practices and market competition together, as visual arts are often valued for the how look in addition to what they mean and what they do. I propose that anthropologists of art may account for visual aesthetics by considering how aesthetic genres categorise and connect art objects, producers and consumers within specific regimes of value.

Sociologists and anthropologists have long acknowledged that art is not produced by a lone genius working solely from her own inspirations. Rather, whole "art worlds" of people, institutions and objects - and their concomitant ideologies - are central to the production of art (Becker 1982; Bourdieu 1993). We cannot assume, therefore, that aesthetics are only produced at the moment of cultural action or production. This may be particularly the case for ethnic arts and crafts like Oaxacan woodcarvings, where "authenticity" and aesthetic conservatism are often expected by consumers, and where particular art world actors may have greater influence on aesthetics than even artists themselves (Steiner 1999; Graburn 2005; Wood 2008:77-114). One significant way that art world actors directly influence artistic production is through the development of genres. In his analysis of Zaire's popular art world, Johannes Fabian argues that the real aesthetic power lies not with those who paint, but with those who classify. He shows that 
over time, these classifications become established genres that direct the visual aesthetics that painters produce. This not only results in different markets for different kinds of artworks, but also constrains future artistic production as these genres become the concepts through which producers and consumers imagine and understand Zairian art, leading them to produce and consume only objects that match the pre-existing conditions of the categories (Fabian 1998: 4851). In other words, the categorical terms used to describe artistic production constitute genres that organise aesthetic difference in ways that are both productive and conservative. While genres may indeed produce striking internal aesthetic coherence, as I will show for the Oaxacan woodcarvers, the power to redefine existing genres also is an important part of aesthetic authority. In order to account for this, I argue that rather than wholly homogenising categories, genres are better understood as relational "aesthetic fields," which I define through reformulating Bourdieu's model of cultural production.

In The Field of Cultural Production (1993), Bourdieu maps out a vision of art that stands against both Kantian notions of aesthetic universality and formalist/structuralist readings of the meaning of art. Like earlier art world theories, he argues that artistic objects are the material results of networks of actors. However, by focusing on the nature of art world relations through his concept of the "habitus," he deepens the analytical capacity of this approach. Each actor's habitus and social relations within an art world, Bourdieu argues, are structured by their position in the overall social field, which is itself structured by the politics of the distribution of capital specific to the art world in question: a combination of symbolic capital (accumulated prestige, knowledge or honour) and recognition by other actors within the field, which he glossed together as "legitimacy" (Bourdieu 1993:30-31; 40-41). Bourdieu's artistic field is thus a relational space 
where the actions and reactions of actors are continually shifting the nature of that space over time, and different artistic fields are delineated by their uses of different kinds of "specific capital," that is, the sources of legitimacy and value that render actors more or less powerful or successful within their given field.

While Bourdieu's insights into the subjective-yet-structured social fields of art production have been helpful for fleshing out and historicising the details of how art worlds work, his model has been critiqued (most recently) by Georgina Born because of its inability to "address the specificity of the art object" or account for the substantive meaning of works of art and why aesthetic formations develop in certain directions over time (Born 2010:177-179). Rather than rejecting the model outright however, I suggest it may be renovated to produce an anthropological approach to art production that can simultaneously account for aesthetic forms and the nature of power within art worlds. I propose that we can re-centre analysis onto art objects and aesthetic processes if we imagine the field itself as an aesthetic rather than social topography, upon which the positions are aesthetically, rather than politically, competitive.

Refiguring Bourdieu's field in this way is useful on two levels: firstly, it allows for divergent aesthetic perspectives to co-exist in the same analysis, meaning that it can also account for changes in aesthetic repertoires, such as those that have recently occurred in Oaxacan woodcarving, as I discuss below. Secondly, it allows room to consider that art objects themselves often have influential power within art worlds, a phenomena that has been provocatively described as the "agency" or "aura" of works of art (Benjamin 2008 [1936]; Gell 1998). Indeed, while Gell's Art and Agency (1998) is often read as an anti-aesthetic theory of art, it substantially 
relies on the sensorily emboldened qualities of art objects for "captivation" and "the abduction of agency" which are at the heart of his approach $(14-16 ; 68-72) .{ }^{6}$ While there is not space here to directly address the theoretical implications of Benjamin's and Gell's work for an anthropological aesthetics, it suffices to say that the auratic or agentive power of art is an important way that aesthetics connect to competition in art markets, as it is a central component of the desirability and authority of certain objects over others within an aesthetic field (cf. Author 2012:38-46). In the next section, I explain the prevailing aesthetics of the Oaxacan woodcarvings genre, which directly relates to local and national understandings of "artesanías" or craftwork. This aesthetic mode has a long and important history in Oaxaca and Mexico more generally, and is the one that informs most artisans' work in San Martín. It is into this aesthetic style that the Garcías are currently inserting an aesthetic of indigeneity which, as I will explore in the final section of the paper, has shifted the genre of Oaxacan woodcarving, and allowed them to become more authoritative and competitive art producers than many of their neighbours.

\section{The aesthetics of artesanías in the nation and the village}

Rufino Pérez is a woodcarver in his early fifties who has also been involved in a variety of artisans' organisations over the years. This work has frequently brought him into contact with ARIPO or the Instituto Oaxaqueño de las Artesanías (Oaxacan Craft Institute), whose intended purpose is to extend support to Oaxacan artisans through fairs and competitions, low-interest loans and small business training and support. ${ }^{7}$ Originally established as a private organisation for the promotion of Oaxacan craftwork, it was absorbed into the state bureaucracy in the 1980s and until recently has been overshadowed financially and organizationally by FONART (Holo 2004: 179-180). Most artisans have ambivalent feelings about dealing with ARIPO; while good relations with staff members may significantly advance individuals' careers or aide the success 
of an event, it is also known to be a highly political and opaque organisation. In addition to rumours of corruption and nepotism, artisans may experience patronizing attitudes and the pressures of personal obligations with some ARIPO staff. Nevertheless, those artisans who seek to elevate the exposure of their work often find dealing with ARIPO unavoidable.

One afternoon while Rufino waited for an appointment at ARIPO, we browsed through the woodcarving display in the gallery attached to their offices. After pointing out some carvings by his brother, he drew me over to a short pedestal standing next to the door. Pointing at the index card accompanying the piece, he proudly told me that he had won a competition a few years earlier. I asked him why he thought his piece had won, and he pointed out the quality of the carving, citing the delicate forms, and also the theme of the piece which was a large nativity scene, painted in bright colours. It was clear that Rufino had spent a lot of time on the piece, and I mentioned that his hard work and skill had obviously impressed the ARIPO judges. He agreed saying he had spent longer on this piece than any other he had made, but said that this was not why he had won. Explaining that all of the artisans who entered the competition were capable of making equally detailed or finely carved work, he thought he had won because his piece was "muy típica" (very typical or representative). I had never seen Rufino sell carvings like the nativity in his workshop, so I asked about the difference in styles. He said that in this case he had adjusted his style because he knew that the judges in government competitions love things that look "really traditional."

Although American collectors have a stronger presence in the academic and popular literature about craft work, Mexican individuals and institutions form a large market for Oaxacan 
woodcarvings. In San Martín, most artisans regularly sell to and take orders from Mexican collectors and wholesalers who prefer aesthetic forms that they describe as "typical" and "quaint," words that connect the carvings to the popular Mexican genre of artesanías (craftwork). In Mexico, the term "artesanía" carries both positive and negative connotations of culturally-inflected, folkloric or traditional material culture of the indigenous and subaltern classes (Bakewell 1995; López 2010), and these connotations directly inform the aesthetic genre of Oaxacan woodcarvings. ${ }^{8}$ Artesanías are highly desirable by large parts of the woodcarvings' art world, especially those who are formally or informally linked to Oaxacan and national state institutions and museums. As many authors have elsewhere described, after the Mexican Revolution in the early twentieth century, the state and intelligentsia in Mexico City sought to consolidate Mexico's ethnic, class and political diversity into a coherent national ideology, founded upon the idealised figure of the mestizo (a person of mixed Spanish and indigenous ancestry). Artesanías were symbolically brought into this configuration to represent the indigenous and subaltern populations' contribution to Mexican culture without opening the door to demands for real social justice and equality (Novelo 1976:30-46; 47-92; García Canclini 1995:118-120). Today, the artesanía category continues to reify (and conflate) indigenous and peasant groups as recognisable and distinctive units within the nation, who often become ideological and aesthetic instruments for the reproduction of Mexican-ness and Oaxacan-ness at official levels (Alonso 2004:467-469; Poole 2009).

The aesthetic content of this category is crucial to its work as a national symbol of belonging; in order to function "as artesanías," hand produced objects must be recognisably Mexican outside of their context of production. Artesanías have a characteristic style, which is 
easily recognisable by most Mexicans as lo folclórico (the folkloric), referring to a specified set of romantic and nostalgic images of countryside, which frequently circulate in material culture and the popular media (D'Ascia 2007:20; Mraz 2009:23-38; 76-79). Lo folclórico also refers to a specific visual repertoire, a certain combination of colours and forms that set artesanías apart from other categories of Mexican material culture and from the material production of nonMexicans. In her study of the Mexico City art world, Liza Bakewell observes that artesanías are expected to be "typically Mexican in palette, shape and sentiment" (1995:20). As one artist explained to her:

"Mexican artesanías embody the real truthful culture, the authentic personality of America - all of Latin America, but especially Mexico. I learned about color from Mexican artesanías. All of it has a lot of color, texture, form. It is a special characteristic of Mexico" (Bakewell 1995:20).

In Mexico City, artesanías have long been established as collectable objects for the political and intellectual elite, as they form material connections between the capital city and the rural countryside where national authenticity is believed to be produced (López 2010:65-94). Oaxacan artesanías in particular have come to represent the state's cultural diversity and distinctive status as an important source of indigenous authenticity within the nation through the art and collections of famous artists, such as Frida Kahlo, and national institutions such as FONART and The Museum of Popular Art. Mexican collectors who place orders for Oaxacan woodcarvings frequently request straightforwardly national symbols, such as the Virgin of Guadalupe, Juan Diego (the Indian peasant who witnessed the Virgin's miracle), or the iconic eagle and snake of the Mexican flag. For their part, many artisans told me they are more 
interested in carving other locally important saints or the Oaxacan Virgin of Juquila, but these figures are less popular with customers from Mexico City and elsewhere in the country.

In Oaxaca, ARIPO directly promotes the artesanía aesthetic through its competitions and programs, as illustrated by the case of Rufino above. All of San Martín's artisans directly or indirectly depend on it for access to markets, sponsorship opportunities and to develop their "names"; throughout my research, I often met ARIPO officials at fiestas for birthdays, baptisms, and weddings, indicating the importance of these personalized relationships for artisans. Because of this, officials' views about what artesanías should look like carry significant weight in terms of defining the visual aesthetics of Oaxacan woodcarving. During an interview with an ARIPO employee, for example, he made it clear that he felt their role was not only to support Oaxaca's artisans financially, but also to "develop an appreciation amongst [them] for quality and beauty and especially for what is authentic and traditional in Oaxaca." Otherwise, he worried, "Oaxaca may become just like any other resort in Mexico, some kind of Disneyland. If artisans do not preserve our true traditions, who will?" Artisans whose aesthetics fit well within the expectations of these institutions are not only more likely to make their "names" through sponsorship and invitations to events, but are also more likely to match touristic expectations of Mexican craftwork, as it is those institutions which frequently set the aesthetic standards through their publications of promotional materials and exporting programmes. As such, it is very risky for artisans not to fall within these institutional aesthetic expectations, as they might be less likely to receive support and recognition at these levels. 
While the interests and discourses that aesthetically frame Oaxacan woodcarvings as artesanías have been successful in establishing a genre that recognisably authenticates them for tourists and collectors, it has also had the effect of constraining the aesthetics of woodcarving, through similar processes to those identified in Zaire by Fabian. This constraint has meant that the vast majority of carvings in San Martín appear to outsiders as "more or less the same," as I was told by more than one visitor, a situation that is exacerbated as more artisans enter the market each year. While making woodcarvings that fall safely within the recognisable genre of artesanías might guarantee a basic return on one's work, the Garcías have attained their success by situating their work outside of the expected genre, and thus creating value through the production of aesthetic difference.

In Oaxaca and Mexico more generally, artesanías (and the folclórico aesthetic) are defined in negative relation to the bellas artes or "high arts". However, this distinction is only partially congruent with how art and craft are usually defined in other Euro-American contexts, as the two are intricately connected through the aesthetic and social networks that developed out of the postrevolutionary nationalist period (Bakewell 1995:22-23). In Oaxaca, the aesthetic line between art and artesanías is rather indistinct, as local fine artists draw heavily on indigenous, peasant or folkloric imagery in their work. ${ }^{9}$ At the same time, these categories remain materially, spatially and economically separate, privileging high arts like painting and print-making over those normally understood as "craftwork" (see Holo 2004). The Garcías have productively positioned themselves at the blurry intersection of these categories by producing objects that can be understood through the general aesthetics of artesanías, while drawing explicit connections to "ethnic art," whose emergence in Oaxaca is inflected by American and Canadian 
understandings. ${ }^{10}$ In so doing they have also shifted the aesthetic field of the Oaxacan woodcarvings, generating new expectations for consumers and state officials alike, who now read their work as indications of authenticity and artistic authority. Ironically, this aesthetic authority translates into their relative economic success because it satisfies the desires of ethnic art consumers for locally-grounded indigenous culture by utilising aesthetics of indigeneity that are not locally produced. As I will show, the Garcías have learned how to signal indigenous ethnicity in ways that are not easily replicated by other artisans in San Martín, making their work appear to be most authentic and culturally valuable, despite the fact that it diverges significantly from the established genre of Oaxacan woodcarving.

\section{"Miguel and Catalina make true ethnic art"}

During my fieldwork, I spent many afternoons in Miguel and Catalina García's workshop to learn about the techniques and rhythms of artisanal work. In the late mornings, groups of tourists from Oaxaca City would often arrive for demonstrations. As the tourists emerged from their tinted-windowed, air conditioned vans, they would find themselves in a tranquil and sunny courtyard, painted in hues of terracotta, with accents of cerulean blue and Mexican pink. "Welcome to my home and our workshop, amigos," Miguel always began in English, as he took his place behind a small table, laden with powders and plant materials. "Today I am going to tell you about our work here and our beautiful village of Tilcajete, which in the Zapotec language means black ink pot."

Unlike the recent history reported by both anthropologists and the Garcías' neighbours, Miguel's demonstrations directly connect the carvings to Oaxaca's pre-Hispanic heritage, often eliding their origin in Arrazola. He explains that that the copal wood used to make the carvings 
has also been used for thousands of years as incense in rituals and ceremonies, and that the original forms of the Oaxacan woodcarvings came from the ancient Mesoamerican calendar, the days of which were named for different animals native to Mexico, which he explains are known as "tonas" or animal spirits in Zapotec. Linking the styles and materials of his work to the ancient Oaxacans whose ruins form key sites within the local tourism geography, he would say: "If you visit the state museum in Oaxaca City, you will see that the ancient Zapotecs always wrote their codices in three colours: black, yellow and red. We can still make these colours today, using natural plants and minerals," which he then demonstrates, producing striking coloured pigments in his palms.

These references to Zapotecness and indigeneity are not only found in the performances that Miguel gives to tourists, but are also apparent in the carvings themselves (Figure 2). Unlike the bright hues associated with artesanías, their work generally utilises the "natural" colour palettes of browns, greens, reds, yellows and turquoise that many American and Canadian consumers identify with indigenous art. While other artisans in San Martín carve saints and skeletons or exaggerated or anthropomorphic animals like lions, giraffes and dragons, the Garcías' repertoire is generally naturalistic representations of animals of the Americas, such as coyotes, bears and jaguars. They decorate these forms with finely detailed painting that includes overt symbols of indigenous culture, such as feathers, masks and the cardinal points, which Miguel and Catalina have elaborated into an explicit system in which each form is said to carry meaning: frogs mean "water,"; triangles mean "mountains."

[FIGURE 2] 
The Garcías' ability to reference indigenous identity in their demonstrations and their art indeed indicates a capacity for "ethnic entrepreneurship." While the direct connections they make between the carvings and indigenous or Zapotec culture are not consistent with the history of Oaxacan woodcarving, they do draw on real expectations that San Martín Tilcajete can be understood as a Zapotec place. While the Zapotec language is no longer spoken in the village, residents know that their grandparents spoke it, and that their ancestors lived in the ruins on the hillside in pre-Hispanic times. Many of the social and religious practices today found in San Martín are also common in nearby Zapotec-speaking communities. By connecting their aesthetics of indigeneity to these local indications of Zapotecness, the Garcías are able to satisfy desires by consumers of ethnic art for objects that are locally-produced by authentic indigenous people. However, the content of their indigenous aesthetics is not, in fact, local. While their woodcarvings appear to be authentic representations of local Zapotec culture, they are in reality more aesthetically aligned with indigenous art sold in the United States than in Oaxaca.

In the last ten years, the Garcías have purposefully cultivated friendships with key American wholesalers and collectors who function as gatekeepers to the tourist and ethnic art markets in the United States. These gatekeepers have aided the Garcías through the obvious routes of providing publicity and introductions to other actors in their networks, but they also work in subtler ways by facilitating opportunities to show their work at a wide variety of museums and up-market galleries in the United States. During these journeys, the Garcías have become familiar with experts' discourses on skill and quality, giving them the language and the means through which to match their work to the expectations of wealthier American consumers and to see how comparable art objects look and are marketed in other locales. In particular, their 
many trips to the Southwest United States over the years have influenced the aesthetic characteristic of the Garcías work, and they now explicitly describe their work as "ethnic art."

In February 2009, I was invited to join Miguel and two other artisans on a sales trip to Tucson, Arizona, where they had been invited to sell their work at a gallery show. At the show, I spoke to a number of collectors as they jostled anxiously around Miguel's table. A number of them had waited since the previous year's sale when Miguel had sold all of his pieces within the first hour. As one customer put it, she needed a piece for her collection, because "Miguel and Catalina make true ethnic art." Like the American wholesalers who sell Zapotec textiles in the United States, the Garcías have recognised that Mexican indigenous identities can be easily subsumed into the aesthetics of ethnic difference that characterise the American Southwest region: design characteristics, such as colour-blocking, figurative patterning, and the use of "earthy" or "desert" palettes, like umber, vermilion, turquoise and jade are easily translated into Mexican aesthetic categories, and the desert landscapes of both Oaxaca and the Southwest have been claimed to influence regional aesthetics (cf. Wood 2008:77-114).

The American Southwest is also a particularly appropriate place for Oaxacan craftwork to be sold because, much like Oaxaca within Mexico, it is often associated with indigeneity and Mexicanness in the national imaginary (Rodríguez 1997; Maruyama, Yen and Stronza 2008). The Southwest also happens to be the location of a particularly robust art market that is focused on ethnic art. Santa Fe, New Mexico is considered to be the third largest art market in the United States, and is focused on the annual Indian Art Market, urban galleries in the Plaza District and the surrounding Pueblo Indian communities (Maruyama, Yen and Stronza 2008:457). While 
many of San Martín's artisans have shown their work in the United States, Miguel and Catalina have had significantly more sustained and intensive interactions with a variety of American ethnic art "experts" - collectors, wholesalers, gallery owners and even museum curators and art instructors at universities. Over time, they have been able to incorporate the subtle and often diffuse expectations of these actors into a coherent aesthetic strategy that is not obvious to artisans who only sell their work in American craft fairs perhaps once every few years.

While many collectors who purchase the Garcías' work uncritically accept the link between an indigenous identity and their carvings, other members of their art world recognise the more active role they have played in cultivating this aesthetic connection. While Miguel was describing the imagery on his carvings in elegant English to the collectors at the Tucson show, his friend and colleague Tommy Bolan told me quietly that "Miguel learned to sell like that in the U.S." Tommy is an American dealer who travels to Mexico many times per year. As time has gone on, he has found it convenient to work quite closely with Miguel; rather than spending many days hunting around the woodcarving villages for stock, he generally now buys most of his supply through the Garcías, much to the disappointment of other artisans with whom he had previously worked. Along with woodcarvings and Oaxacan textiles, Tommy also specialises in delicate, expensive pottery from the mestizo community of Mata Ortiz, in the northern Mexican state of Chihuahua. This pottery is known for its fine etching and detailed geometric patterns that are created in glazes before firing. Like Oaxacan woodcarvings, Mata Ortiz pottery was "invented" in the twentieth century and draws on both Mesoamerican and Aboriginal North American aesthetic conventions (Parks 1997). In two different interviews, Tommy pointed out that the Mata Ortiz pottery had a direct aesthetic influence on Miguel and Catalina's style of 
painting, and that Miguel would never have seen it if it had not been for their friendship. Indeed, the similarities between the pottery and the Garcías' work are striking (Figures 2 and 3). Miguel and Catalina themselves do not deny this connection, but say that instead they have incorporated the "feeling" (el sentimiento) of Mata Ortiz work, rather than directly copying its style. This example illustrates the extent to which the aesthetics of indigeneity in Mexico do not only emerge "organically" from the lived experiences of indigenous peoples, but also are selfconsciously elaborated and circulated through the different art markets in which Mexican artisans work.

[FIGURE 3]

The Garcías’ process of incorporation and elaboration of indigenous aesthetics - what Arnd Schneider (2006) helpfully theorises as a "practice of appropriation" - has taken place over a number of years. After the Tucson show was over Erin Kers, an American woman who knew the Garcías through her previous work at a world art gallery in California, invited us to her home for dinner. As they reminisced about the past, Erin mentioned that she had carvings by Miguel in "his old style." When I asked what that meant, she pointed to some pieces that were displayed in her living room, indicating a large one on the left (Figure 4). Laughing, Miguel said "yes, my work has really changed since then." Miguel later explained to me that when he first started carving he did not know what kinds of things he should make, but that he learned from looking at the work of other artisans. He explained that he made this Mickey Mouse carving because he thought that people would want figures of popular characters, but said that it was during his early sales trips he began to develop his own style. On these trips he was able to see what kind of objects sold well, and he was able to talk to collectors and wholesalers, from whom he learned 
more about the history of ethnic art and artesanías. He said, "Once I started going to the States, my work changed very rapidly. I had so many inspirations from all different kinds of work, and I could talk to those expert collectors who really knew about our kind of art."

[FIGURE 4]

By linking Oaxacan woodcarvings to an ethnic art aesthetic of indigeneity, the Garcías assert that Oaxacan artisans' genealogical connection to their Zapotec ancestors is a significant part of their artistic production today. This not only renders their work "authentic" within the North American context of ethnic art collection, but it also satisfies contemporary Mexican national understandings that have historically valued "safe" indigenous cultural production as a keystone of the nation's distinctiveness. While Miguel's earlier "Mickey Mouse" carving would have struggled to sustain this level of aesthetic authority, the Garcías' current work seamlessly attaches itself to the common sense understandings of indigenous art that circulate within both of these art worlds that link objects to culture, history and identity (cf. Townsend Gault 2001:240243).

Because of their popularity in the United States, and the prices that their carvings command, Miguel and Catalina are increasingly authority figures within the art world of Oaxacan art and artesanías. They are frequently invited to attend openings and events in Oaxaca City, which is the centre of its own important fine art market (Holo 2004: 59-101), and they have cultivated relationships with high level government officials and members of Oaxaca's press and tourism industries. As many of these people have not traditionally been within the woodcarvings' 
art world, the Garcías' indigenised Oaxacan woodcarvings now circulate in ways that the products of other artisans cannot do. The frequent recurrence of the Garcías' ethnicised explanations within these popular and wide networks of actors means that "their version" of woodcarving aesthetics has gained authority and legitimacy, not only consolidating their success in Oaxaca, but also affecting the authority and aesthetic legitimacy of other artisans within traditional artesanía markets. Their ethnic art aesthetics are now often promoted in Spanish and English advertisements and articles throughout Mexico and North America. Many of these articles feature interviews with Miguel or Catalina, and often include their explanation of the woodcarvings as the product of their indigenous or Zapotec culture, a trope that is now often picked up by tour guides who bring tourists to San Martín or gallery owners in Oaxaca City.

Connecting the Garcías' success to their ability to produce a convincing aesthetics of indigeneity, therefore, not only allows us to understand why they have become more successful than their neighbours in terms of the ethnic art market, but also illuminates something important about the nature of competition in cultural markets itself. I have suggested that approaching aesthetics at the level of genre, rather than individual artists, allows for the relationships between actors in art worlds to be analytically connected to artistic production. If we conceptualise genres as aesthetic topographies upon which artists compete with one another for aesthetic legitimacy, then we can see that the Garcías' successful engagement with indigeneity necessarily constitutes a change in the entire genre of Oaxacan woodcarving, and hence also affects the aesthetic authority and legitimacy of other artisans working in the same field. As the authority and value of the Garcías' work expands in Oaxaca, the woodcarvings produced by other artisans in San Martín are also increasingly evaluated by reference to the Garcías' work which, as it has set the new standards itself, inevitably appears more authentic and true. In response, a few artisans in 
San Martín have attempted to incorporate an aesthetics of indigeneity into their work. Some utilize widely recognized local symbols of Zapotecness, such as the "grecas" pattern from the ruins at Mitla that is also often replicated in textiles or even more unmistakable representations of the ancient Zapotecs, like pyramids and jaguars. However, these carvings are generally still executed within the artesanías aesthetic in terms of colour, style and form, and do not connect in the same way to the expectations of "ethnic art" now held by certain consumers. Other artisans in San Martín have attempted to develop their work towards this ethnic art aesthetic, but as many only have access to a few of the Garcías' pieces that are displayed in local museums as examples of indigenous art, their attempts have (so far) been deemed "mere copies" by consumers and other artisans. As the apparently locally-grounded aesthetics of indigeneity utilised by the Garcías is not actually local in its inspiration, other artisans with less experience abroad are unable to produce "indigenous art" that appears sufficiently local and authentic. The consequences of these processes for the Oaxacan woodcarving genre mean that its aesthetic field, and its concomitant relations of power and competition, are fundamentally altered as different kinds of references to indigeneity also become unevenly valued and evaluated vis-à-vis one another.

\section{Conclusion}

Markets for cultural goods, such as ethnic art, craftwork, food and music, have provided a rich seam of data for anthropologists to test their theories of culture and of economics. At least since the publication of James Clifford's The Predicament of Culture in 1988, we have frequently 
turned our attention to both the actors and social structures that produce economic and social value out of cultural difference. While this work has usefully unravelled the entangled intentions and desires of cultural producers, states, consumers and other market actors, we must also pay attention to how aesthetic desires and expectations are also central to these processes. Competition in ethnic art markets cannot be fully understood without a consideration of the objects that are being bought and sold. The sensory qualities of these objects are central to their value, as it is most often how they look, feel and sound, that distinguish them from the products of other cultures and from industrially produced commodities. In other words, the aesthetics of cultural goods are a central component of value and competition in cultural markets.

I have suggested that aesthetics of visual arts and other cultural goods can be approached ethnographically by considering how genres are constituted, maintained and changed by the actors involved in art worlds. Conceptualising aesthetics in this way allows us to connect the social relations of actors to the material and aesthetic processes that are at the heart of producing and circulating art. In the case described here, this approach allowed insight into how Miguel and Catalina García were able to successfully enter a new art market by aligning their aesthetics to the expectations of that market, and also how their success fundamentally changed the nature of the competition amongst Oaxacan woodcarvers. By successfully drawing on an aesthetics of indigeneity that speaks to the North American ethnic art market in ways that their neighbours cannot replicate, the Garcías appear at once more authoritative and more authentic than their competitors, some of whom have been producing carvings for much longer. This case shows that by charting the relations between aesthetic practices and social, economic and political forms, we can move beyond interests of "discourse" in our analyses to focus more firmly on the relations 
between people and objects, an analytical imperative that has been important within anthropology for at least the last ten years. Approaching aesthetics as a relational process provides us a frame through which we may connect the affective and sensory experiences of social life to more established anthropological interests of power, economy and society. While aesthetics indeed provides a way forward to account for the "sensuous participation" of individuals as they create and construct their social worlds, the example of Oaxacan woodcarving shows that we must not assume aesthetic participation is the antithesis to the exercise of power; often the two go hand in hand.

\section{Notes}

${ }^{1}$ The Manitas Mágicas program is produced and managed on behalf of FONART by Comunicación Comunitaria, a non-profit organisation dedicated to promoting and preserving artistic and artisanal education and rights in Mexico.

${ }^{2}$ All personal names are pseudonyms.

${ }^{3}$ Unlike many other communities, San Martín Tilcajete holds both comunal and ejidal forms of collective land titles. Usos y costumbres was sanctified under reforms to Oaxaca's constitution in 1995 and was intended to legally recognise existing political regimes in indigenous communities. For critical analyses of this process see work by Alejandro Anaya Muñoz, Jorge Hernández Díaz and Todd Eisenstadt.

${ }^{4}$ Many of these commercial workshops also sell carvings wholly or partially produced in the more remote village of San Pedro Taviche from where a large amount of copal wood is also derived (cf. Chibnik 2003:50-51).

${ }^{5}$ Jiménez passed away in 2005, but his sons continue to work as artisans in Arrazola.

${ }^{6}$ Despite Gell's memorable "methodological philistinism" and his own opposition to the study of aesthetics as an anthropological project (1998: 1-11), Art and Agency is to my mind theoretically consistent with the newer approaches to aesthetics in anthropology discussed here.

${ }^{7}$ In 2004, ARIPO (Artesanías and Popular Industries of the State of Oaxaca) changed its name to the Oaxacan Craft Institute. Most people in Oaxaca continue to refer to it as ARIPO.

${ }^{8}$ Elsewhere I have argued that the term "artesanía" in its Mexican usage cannot be straightforwardly translated as "craft," as the historical and contemporary connotations associated with these words vary greatly between the Mexican context and English-speaking Europe and North America (Author 2012:49-52).

${ }^{9}$ This is evident, for example, in the work of Oaxaca's two most famous painters, Francisco Toledo and Rufino Tamayo.

${ }^{10}$ Street art is another important genre of work that has emerged relatively recently in Oaxaca and has important political, social and aesthetic implications for Oaxaca (see Arenas 2011). 


\section{References Cited}

Alonso, Anna María. 2004. Conforming Disconformity: "Mestizaje," Hybridity, and the Aesthetics of Mexican Nationalism. Cultural Anthropology 19(4):459-490.

Arenas, Ivan. 2011. Rearticulating the Social: Spatial Practices, Collective Subjects, and Oaxaca's Art of Protest. Unpublished doctoral dissertation. Department of Anthropology, University of California, Berkeley.

Bakewell, Liza. 1995. "Bellas Artes" and "Artes Populares": The Implications of Difference in the Mexico City Art World. In Looking High and Low: Art and Cultural Identity, edited by Brenda Jo Bright and Liza Bakewell, pp. 19-54. Tucson: University of Arizona Press.

Becker, Howard. 1982. Art Worlds. Berkeley: University of California Press.

Benjamin, Walter. 2008 [1936]. The Work of Art in the Age of Mechanical Reproduction, translated by J.A. Underwood. London: Penguin Books.

Born, Georgina. 2010. The Social and the Aesthetic: For a Post-Bourdieuian Theory of Cultural Production. Cultural Sociology 4:171-208.

Bourdieu, Pierre. 1993. The Field of Cultural Production: Essays on Art and Literature. New York: Columbia University Press.

Brown, Denise F. 1999. Mayas and Tourists in the Maya World. Human Organization 58(3): 295-304.

Brulotte, Ronda. 2013. Between Art and Artifact: Archaeological Replicas and Cultural Production in Oaxaca, Mexico. Austin: University of Texas Press.

Bruner, Edward. 1996. Tourism in the Balinese Borderzone. In Displacement, Diaspora and Geographies of Identity edited by Smadar Lavie and Ted Swedenburg, pp. 157-179. Chapel Hill: Duke University Press.

Chibnik, Michael. 2003. Crafting Tradition: The Making and Marketing of Oaxacan Woodcarvings. Austin: University of Texas Press.

------ 2006. Oaxacan Woodcarvings in the World of Fine Art: Aesthetic Judgements of a Tourist Craft. Journal of Anthropological Research 62(4):491-512.

Clifford, James. 1988. The Predicament of Culture: Twentieth Century Ethnography, Literature and Art. Cambridge: Harvard University Press. 
Cohen, Jeffrey. 1999. Cooperation and Community: Economy and Society in Oaxaca. Austin: University of Texas Press.

Colloredo-Mansfeld, Rudi. 2002. An Ethnography of Neoliberalism: Understanding Competition in Artisan Economies. Current Anthropology 43(1):113-137.

----- 2011. Work, Cultural Resources, and Community Commodities in the Global Economy. Anthropology of Work Review 32:51-62.

Comaroff, John L. and Jean Comaroff. 2009. Ethnicity, Inc. Chicago: University of Chicago Press.

D’Ascia, Luca. 2007. ¿Quién Habla En La Oreja De Einstein? Arte Indígena Contemporáneo En El Estado De Chiapas (México). Boletín de Antropología (Universidad De Antioquia, Medellín, Colombia) 21(38):11-40.

De Hart, Monica C. 2010. Ethnic Entrepreneurs: Identity and Development Politics in Latin America. Stanford: Stanford University Press.

Fabian, Johannes 1998. Moments of Freedom: Anthropology and Popular Culture. Charlottesville: University Press of Virginia.

García Canclini, Néstor. 1995. Hybrid Cultures: Strategies for Entering and Leaving Modernity. Minneanapolis: University of Minnesota Press.

Gell, Alfred. 1998. Art and Agency: An Anthropological Theory. Oxford: Oxford University Press

Graburn, Nelson. 2005. From Aesthetics to Prosthetics and Back. Materials, Performance and Consumers in Canadian Inuit Sculptural Arts; or, Alfred Gell in the Canadian Arctic. In Les Cultures à L'oeuvre-Rencontres En Art, edited by Michèle Coquet et al, pp. 47-62 Paris: Biro Editeur.

Hernández Díaz, Jorge and Gloria Zafra. 2005. Artesanas y artesanos: Creación, innovación y tradición en la producción de artesanías. Mexico City, Mexico: Plaza y Valdes.

Holo, Selma. 2004. Oaxaca at the Crossroads: Managing memory, negotiating change. Washington D.C.: Smithsonian Books.

López, Rick A. 2010. Crafting Mexico: Intellectuals, Artisans and the State after the Revolution. Durham: Duke University Press

Makovicky, Nicolette 2010. 'Something to Talk About': Notation and Knowledge-making Among Central Slovak Lace-makers. Journal of the Royal Anthropological Institute 16(S1):S80-S99. 
Marchand, Trevor. 2009. The Masons of Djenné. Bloomington: University of Indiana Press.

Maruyama, Naho, Tsu-Hong Yen and Amanda Stronza. 2008. Perception of Authenticity of Tourist Art Among Native American Artists in Santa Fe, New Mexico. International Journal of Tourism Research 10:453-466.

Meyer, Birgit. 2009. Aesthetic Formations. Media, Religion and the Senses. London: Palgrave MacMillan

Meisch, Lynn. 1995. Gringas and Otavaleños: Changing Tourist Relations. Annals of Tourism Research. Annals of Tourism Research 22(2):441-462.

Mohsini, Mira. forthcoming. Highly skilled labor: Troubling the categories of "artisan" and "labor" In Taking Stock: Critical Craft Studies, edited by Clare Wilkinson Weber and Alicia Ory de Nicola.

Morphy, Howard, and Morgan Perkins. 2006. The Anthropology of Art: Reflection on its History and Contemporary Practice. In The Anthropology of Art: A Reader, edited by Howard Morphy and Morgan Perkins, pp. 1-32. London: Blackwell.

Morphy, Howard, et al 1996. Debate: Aesthetics Is a Cross-Cultural Category. In Key Debates in Anthropology, edited by Tim Ingold, pp. 251-293. London: Routledge.

Mraz, John. 2009. Looking for Mexico: Modern Visual Culture and National Identity. Durham: Duke University Press.

Myers, Fred. 2002. Painting Culture: The Making of an Aboriginal High Art. Durham: Duke University Press

Novelo, Victoria. 1976. Artesanías y Capitalismo en México. Mexico City: Instituto Nacional de Antropología e Historia.

Parks, Walter P. 1997. The Miracle of Mata Ortiz: Juan Quezada and the Potters of Northern Chihuahua. Riverside: Coulter Press.

Pinney, Christopher. 2004. 'Photos of the Gods': The Printed Image and Political Struggle in India. London: Reaktion Books.

Poole, Deborah. 2009. Affective Distinctions Race and Place in Oaxaca. In Contested Histories in Public Space: Memory, Race, and Nation, edited by Daniel J. Walkowitz and Lisa M. Knauer, pp. 197-225. Durham, NC, USA: Duke University Press.

Rodríguez, Sylvia 1997. The Taos Fiesta: Invented Tradition and the Infrapolitics of Symbolic Reclamation. Journal of the Southwest 39(1): 33-57.

Rowlands, Michael. 2011. Of substances, palaces, and museums: the visible and the invisible in the constitution of Cameroon. Journal of the Royal Anthropological Institute 17:S23-S38. 
Schneider, Arnd. 2006. Appropriation as Practice: Art and identity in Argentina. Basingstoke: Palgrave MacMillan.

Sharman, Russell L. 2006. Re/Making La Negrita: Culture as an Aesthetic System in Costa Rica. American Anthropologist 108(4):842-853.

Steiner, Christopher. 1999. Authenticity, Repetition and the Aesthetics of Seriality: The Work of Tourist Art in the Age of Mechanical Reproduction. In Unpacking Culture: Art and Commodity in Colonial and Postcolonial Worlds, edited by Ruth Phillips and Christopher Steiner, pp. 87-103. Berkeley: University of California Press.

Stephen, Lynn. 2005. Zapotec Women: Gender, Class, and Ethnicity in Globalized Oaxaca. (2nd edition). Durham: Duke University Press

Svašek, Maruška. 2007. Anthropology, Art and Cultural Production. Ann Arbor: Pluto Press.

Terrio, Susan J. 1999. Performing Craft for Heritage Tourists in Southwest France. City and Society 11(1):125-144.

Townsend-Gault, Charlotte. 2001. When the (Oven) Gloves Are Off: The Queen's Baton - Doing What to Whom? In Beyond Aesthetics: Art and the Technologies of Enchantment, edited by Christopher Pinney and Nicholas Thomas, pp. 87-103. Oxford: Berg.

Werbner, Pnina and Mattia Fumanti. 2013. The Aesthetics of Diaspora: Ownership and Appropriation. Ethnos 78(2):149-174.

Wood, William W. 2008. Made in Mexico: Zapotec Weavers and the Global Ethnic Art Market. Indianapolis: University of Indiana Press 


\section{Figure Captions}

Figure 1 - A typical Oaxacan Woodcarving (p. 7)

Figure 2 - A woodcarving by Miguel and Catalina García (p. 22)

Figure 3 - Mata Ortiz pottery from Chihuahua, Mexico (p. 26)

Figure 4 - Early piece by Miguel García made circa 1993 (p. 27) 